\title{
Faktor yang Berhubungan Dengan Penggunaan Kontrasepsi Pada Wanita Dengan Pernikahan Usia Dini
}

\author{
Herlina Simanjuntak $^{1}$, Fika Ayu Maynia ${ }^{2}$ \\ 1,2 Institut Medika Drg Suherman Prodi D3 Kebidanan
}

\begin{tabular}{l}
\hline INFORMASI ARTIKEL: \\
\hline Riwayat Artikel: \\
Tanggal diterima: Januari 13, 2018 \\
Tanggal di revisi: Maret 10, 2018 \\
Tanggal di Publikasi: Maret 20, 2018 \\
\hline
\end{tabular}

Kata kunci:

Wanita nikah usia dini, kontrasepsi, pengetahuan, pendidikan, dukungan suami, sumber informasi. alat bantu ajar, AKDR, low-cost, realistis, awet,

Key Word :

Early marriage, contraception, knowledge, education, support of husband.

Contact:

herlina.simanjuntak09@gmail.com

\begin{abstract}
A B S T R A K
Proporsi penggunaan kontrasepsi dikalangan wanita nikah usia dini masih rendah. Jika wanita nikah usia dini tidak mengatur atau merencanakan kehamilan dampak yang terjadi adalah peningkatan jumlah penduduk dan masalah kesehatan reproduksi. Sehingga penelitian ini ditujukan untuk mengetahui faktor-faktor yang berhubungan dengan penggunaan kontrasepsi pada wanita nikah usia dini. Studi cross sectional dilakukan dengan melibatkan 53 orang wanita nikah usia dini di Desa Banjarsari, yang diambil secara total sampling. Subyek penelitian yang memenuhi kriteria sampel diwawancara menggunakan kuesioner untuk mendapatkan data penggunaan kontrasepsi, pengetahuan, tingkat pendidikan, dukungan suami serta sumber Informasi. Data dianalisis secara univariat dan bivariat dengan uji chi square. Hasil penelitian didapatkan sebagian besar pengguna kontrasepsi pada wanita nikah usia dini memiliki pengetahuan baik $(86,2 \%)$ dengan $\mathrm{p}$ value $=0,001$, tingkat pendidikan tinggi $(76,9 \%)$ dengan $p$ value $=0,004$, mendapat dukungan suami $(92,9 \%)$ dengan $p$ value $=0,000$, serta mendapatkan informasi dari tenaga kesehatan $(87,2 \%)$ dengan $p$ value $=0,000$. Sehingga dapat disimpulkan bahwa pengetahuan, tingkat pendidikan dukungan suami dan sumber informasi merupakan faktor-faktor yang berhubungan dengan penggunaan kontrasepsi pada wanita nikah usia dini.
\end{abstract}

\section{A B S T R A C T}

The proportion of the use of KB (family planning program) by early marriage women is low. The aimed of this studi is to identify related factors to contraception use among early marriage women in Banjarsari village, district of Sukatani, Bekasi regency. A cross sectional study was done involving 53 women with early marriage, sampling by total sampling. The subject which sample criteria were interviewed using questionnaires to obtain data of the use of contaception, knowledge, education level, occupation, support of husband and information sources. The data were analyzed in both univariate and bivariate using chi square test. The findings show that most of contraceptive users were women with early marriage knowledgeable (86.2\%) with $p$ value of 0.001 , experiencing higher education (76.9\%) with $\mathrm{p}$ value of 0,004 , supported by husband $(92.9 \%)$ with $\mathrm{p}$ value of 0.000 and getting information from health workers $(87.2 \%)$ with $\mathrm{p}$ value of 0.000 . The conclusion of this study show that knowledge, education level, support of husband and sources of information are factors relating to the use of contraception among early marriage women. 


\section{PENDAHULUAN}

Tingginya angka kelahiran disebabkan oleh banyaknya pernikahan yang terjadi, terlebih lagi cukup banyak masyarakat Indonesia yang menikah pada usia dini sehingga risiko untuk melahirkan anak lebih banyak daripada yang menikah pada usia yang lebih dewasa. Hal ini disebabkan wanita yang menikah di bawah usia 20 tahun memiliki rentang masa subur yang lebih panjang. Berdasarkan Riskesdas (2013) proporsi penggunaan kontrasepsi pada wanita nikah usia muda masih rendah dan mereka tergolong ke dalam kelompok berisiko usia 15 19 tahun. Proporsi pengunaan kontrasepsi pada kelompok berisiko adalah sebesar $46 \%$ angka ini masih lebih rendah bila dibandingakan dengan targert RPJM 2014 yaitu 60,1\%. Penggunaan kontrasepsi wanita menikah usia dini di Jawa Barat

Kehamilan dan persalinan usia dini meningkatkan risiko komplikasi saat kehamilan misalnya anemia, persalinan prematur, keguguran, pendarahan, dan berat badan lahir bayi rendah, hal ini yang akan meningkatkan risiko terjadinya kematian pada ibu dan bayi. Selain itu, pernikahan di usia dini juga dapat menyebabkan gangguan perkembangan kepribadian dan anak yang dilahirkan berisiko terhadap kejadian kekerasan dan keterlantaran (Fadlyana dan Larasaty, 2009). Dari segi mental seorang ibu yang hamil usia kurang dari 20 tahun belum siap menghadapi perubahan saat terjadi kehamilan dan berperan menjadi seorang ibu untuk anaknya serta menghadapi permasalahan-permasalahan dalam rumah tangganya.

Kehamilan pada wanita nikah usia dini dapat dicegah melalui pengunaan kontrasepsi. Beberapa faktor yang menghambat wanita usia dini untuk mendapatkan pelayanan kontrasepsi adalah kurangnya pengetahuan tentang kontrasepsi dan dimana mereka bisa mendapatkannya, selain itu tekanan sosial yang mengharuskan mereka untuk segera memiliki keturuan setelah menikah.

Berdasarkan uraian masalah di atas maka penelitian ini bertujuan untuk mengetahui faktor-faktor yang berhubungan dengan penggunaan kontrasepsi pada wanita nikah usia dini di Desa Banjarsari Kecamatan Sukatani Kabupaten Bekasi..

\section{METODE PENELITIAN}

Penelitian ini merupakan studi analitik kuantitatif dengan analisis kolerasi antara fenomena atau antara faktor risiko dengan faktor efek. (Notoatmodjo, 2010). Desain yang digunakan adalah cross sectional. Data yang dikumpulkan adalah data primer yaitu usia saat menikah pertama, penggunaan kontrasepsi, pendidikan, pengetahuan, pekerjaan, dukungan suami, dan sumber informasi.

\section{HASIL PENELITIAN}

Tabel 1. Distribusi frekuensi penggunaan kontrasepsi dan karakteristik pada wanita nikah usia dini

\begin{tabular}{lll}
\hline Variabel & N & \% \\
\hline Penggunaan kontrasepsi & & \\
Tidak & 19 & 35,8 \\
Ya & 34 & 64,2 \\
Pengetahuan & & \\
Kurang & 24 & 45,3 \\
Baik & 29 & 54,7 \\
Tingkat Pendidikan & & \\
Rendah & 14 & 26,4 \\
Tinggi & 39 & 73,6 \\
Dukungan suami & & \\
Kurang & 25 & 47,2 \\
Baik & 28 & 52,8 \\
Sumber Informasi & & \\
Non Tenaga Kesehatan & 14 & 26,4 \\
Tenaga Kesehatan & 39 & 73,6 \\
\hline
\end{tabular}

Berdasarkan Tabel 1, dapat dilihat bahwa dari 53 responden, 19 orang $(35,8 \%)$ tidak menggunakan kontrasepsi dan sisanya 34 orang (64,2\%) menggunakan kontrasepsi. Terdapat 24 orang $(45,3 \%)$ memiliki pengetahuan kurang dan sisanya 29 orang $(54,7 \%)$ memiliki pengetahuan baik, 14 orang $(26,4 \%)$ memiliki pendidikan rendah dan sisanya 39 orang $(73,6 \%)$ memiliki pendidikan tinggi. Terdapat 25 orang $(47,2 \%)$ dengan dukungan kurang dari suaminya untuk melakukan KB dan sisanya 28 orang $(52,8 \%)$ mendapatkan dukungan dari suaminya untuk melakukan KB, 14 orang $(26,4 \%)$ mendapatkan 
informasi dari non tenaga kesehatan dan sisanya 39 orang $(73,6 \%)$ mendapatkan informasi dari tenaga kesehatan.

Tabel 2. Hubungan pengetahuan dengan penggunaan kontrasepsi pada wanita nikah usia dini di Desa Banjarsari Kecamatan Sukatani Kabupaten Bekasi.

\begin{tabular}{llllllll}
\hline \multirow{2}{*}{$\begin{array}{l}\text { Pengetah } \\
\text { uan }\end{array}$} & \multicolumn{2}{l}{ Yenggunaan Kontrasepsi } & Total & & $\begin{array}{l}\text { p. } \\
\text { Val } \\
\text { ue }\end{array}$ \\
\cline { 2 - 7 } & $\mathbf{n}$ & $\mathbf{9}$ & $\mathbf{n}$ & $\mathbf{\%}$ & $\mathbf{n}$ & $\mathbf{\%}$ & \\
\cline { 2 - 7 } Baik & 25 & 86,2 & 4 & 13,8 & 29 & 100 & $\mathbf{0 , 0 0}$ \\
Kurang & 9 & 37,5 & 15 & 62,5 & 24 & 100 & $\mathbf{1}$ \\
Total & 34 & 64,2 & 19 & 35,8 & 53 & 100 & \\
\hline
\end{tabular}

Berdasarkan hasil analisis bivariat pada Tabel 2, diperoleh nilai $p$ Value $0,001(<\alpha 0,05)$. Hal ini menunjukan bahwa Ho ditolak, maka dapat disimpulkan terdapat hubungan secara statistik antara pengetahuan dengan penggunaan kontrasepsi pada wanita nikah usia dini

Tabel 3. Hubungan tingkat pendidikan dengan penggunaan kontrasepsi pada wanita nikah usia dini di Desa Banjarsari Kecamatan Sukatani Kabupaten Bekasi

\begin{tabular}{llllllll}
\hline & \multicolumn{3}{c}{$\begin{array}{l}\text { Penggunaan } \\
\text { Kontrasepsi }\end{array}$} \\
\cline { 2 - 6 } $\begin{array}{l}\text { Tingkat } \\
\text { pendidik }\end{array}$ & Ya & \multicolumn{3}{c}{ Tidak } & & $\begin{array}{l}\text { p. } \\
\text { Val } \\
\text { ue }\end{array}$ \\
\cline { 2 - 7 } & n & $\%$ & n & $\%$ & n & \% & $\begin{array}{l}\text { 0,0 } \\
\mathbf{0 4}\end{array}$ \\
\hline Tinggi & 30 & 76,9 & 9 & 23,1 & 39 & 100 & \\
\hline Rendah & 4 & 28,6 & 10 & 71,4 & 14 & 100 & \\
\hline Total & 34 & 64,2 & 19 & 35,8 & 53 & 100 & \\
\hline
\end{tabular}

Berdasarkan hasil analisis bivariat pada Tabel 3, diperoleh nilai $p$ Value $0,004(<\alpha 0,05)$. Hal ini menunjukan bahwa Ho ditolak, maka dapat disimpulkan terdapat hubungan secara statistik antara tingkat pendidikan dengan penggunaan kontrasepsi pada wanita nikah usia dini
Tabel 4. Hubungan dukungan suami dengan penggunaan kontrasepsi pada wanita nikah usia dini di Desa Banjarsari Kecamatan Sukatani Kabupaten Bekasi.

\begin{tabular}{|c|c|c|c|c|c|c|c|}
\hline \multirow{3}{*}{$\begin{array}{l}\text { Dukungan } \\
\text { suami }\end{array}$} & \multicolumn{4}{|c|}{$\begin{array}{l}\text { Penggunaan } \\
\text { Kontrasepsi }\end{array}$} & \multirow{2}{*}{\multicolumn{2}{|c|}{ Total }} & \multirow[t]{3}{*}{ p. Value } \\
\hline & \multicolumn{2}{|l|}{ Ya } & \multicolumn{2}{|c|}{ Tidak } & & & \\
\hline & $\mathbf{n}$ & $\%$ & $\mathbf{n}$ & $\%$ & $\mathbf{n}$ & $\%$ & \\
\hline Mendukung & 26 & 92,9 & 2 & 7,1 & 28 & 100 & \\
\hline $\begin{array}{l}\text { Kurang } \\
\text { mendukung }\end{array}$ & 8 & 32 & 17 & 68 & 25 & 100 & 0,000 \\
\hline Total & 34 & 64,2 & 19 & 35,8 & 53 & 100 & \\
\hline
\end{tabular}

Berdasarkan hasil analisis bivariat pada Tabel 4, diperoleh nilai $p$ Value $0,000(<\alpha 0,05)$. Hal ini menunjukan bahwa Ho ditolak, maka dapat disimpulkan terdapat hubungan secara statistik antara dukungan suami dengan penggunaan kontrasepsi pada wanita nikah usia dini.

Tabel 5. Hubungan sumber informasi dengan penggunaan kontrasepsi pada wanita nikah usia dini di Desa Banjarsari Kecamatan Sukatani Kabupaten Bekasi.

Berdasarkan hasil analisis bivariat pada Tabel 5, diperoleh nilai $p$ Value $0,000(<\alpha 0,05)$. Hal ini menunjukan bahwa Ho ditolak, maka dapat disimpulkan terdapat hubungan secara statistik antara sumber informasi dengan penggunaan

\begin{tabular}{|c|c|c|c|c|c|c|c|}
\hline \multirow{3}{*}{$\begin{array}{l}\text { Sumber } \\
\text { informasi }\end{array}$} & \multicolumn{4}{|c|}{$\begin{array}{l}\text { Penggunaan } \\
\text { Kontrasepsi }\end{array}$} & \multicolumn{2}{|c|}{ Total } & \multirow[t]{3}{*}{$\begin{array}{l}\text { p. } \\
\text { Value }\end{array}$} \\
\hline & \multicolumn{2}{|c|}{$\mathbf{Y a}$} & \multicolumn{2}{|c|}{ Tidak } & \multirow[b]{2}{*}{ n } & \multirow[b]{2}{*}{$\%$} & \\
\hline & $\mathbf{n}$ & $\%$ & n & $\%$ & & & \\
\hline Nakes & 34 & 87,2 & 5 & 12,8 & 39 & 100 & \\
\hline $\begin{array}{l}\text { Non } \\
\text { Nakes }\end{array}$ & 0 & 0 & 14 & 100 & 14 & 100 & 0,00 \\
\hline Total & 34 & 64,2 & 19 & 35,8 & 53 & 100 & \\
\hline
\end{tabular}

kontrasepsi pada wanita nikah usia dini.

\section{PEMBAHASAN}

Hubungan antara Pengetahuan dengan Penggunaan Kontrasepsi pada Wanita Nikah Usia Dini di Desa Banjarsari Kecamatan Sukatani Kabupaten Bekasi. 
Berdasarkan hasil penelitian pada tabel 2 terdapat 15 wanita nikah usia dini $(62.5 \%)$ memiliki pengetahuan kurang dan tidak menggunakan kontrasepsi. Hasil analisa data tersebut secara statistik menunjukkan nilai bermakna $\mathrm{p}=0.001$. Pengetahuan tentang manfaat kontrasepsi pada wanita nikah usia dini memiliki keterbatasan karena waktu yang seharusnya digunakan untuk memperoleh pengetahuan tetapi digantikan dengan peran baru menjadi sebagai seorang istri yang harus mengurus keperluan rumah tangga dan keluarga.

Faktor-faktor yang berpengaruh terhadap pengetahuan seseorang tentang penggunaan kontrasepsi yaitu pendidikan, sumber informasi dan ekonomi, lingkungan, dan pengalaman. Pendidikan yang tinggi akan memudahkan seseorang untuk menerima informasi, baik yang diperoleh dari orang lain maupun dari media masa. Semakin baik informasi yang diperoleh seseorang makin baik pula pengetahuan seseorang tentang kesehatan.Eliason,et all.(2014)

Hasil penelitan sesuai dengan penelitian Chernick et all (2015) yaitu ketidakpahaman seorang remaja perempuan tentang cara kerja dan manfaat kontrasepsi membuat mereka enggan menggunakan kontrasepsi.

Hubungan Tingkat Pendidikan dengan Penggunaan Kontrasepsi pada Wanita Nikah Usia Dini di Desa Banjarsari Kecamatan Sukatani Kabupaten Bekasi

Hasil peneltian yang didapatkan dari tabel 3 menunjukkan 10 orang (71.4\%) yang tingkat pendidikan rendah tidak menggunakan kontrasepsi. Pendidikan merupakan salah satu faktor yang menentukan dalam penggunaan kontrasepsi. Seseorang yang berpendidikan tinggi akan lebih luas pandangannya dan lebih mudah menerima ide dan tata cara kehidupan baru. Hasil penelitan ini sesuai dengan). Wanita yang berpendidikan akan memiliki lebih banyak pengetahuan tentang alat atau cara KB tertentu beserta pengaruhnya pada kesehatan. Dengan demikian, mereka bisa menghindari kemungkinan terjadinya kehamilan yang tidak direncanakan. Berdasarkan hasil penelitian ini, semakin tinggi pendidikan seseorang maka semakin tinggi pula kemungkinan untuk menggunaan kontrasepsi. Rizkianti, dkk (2017)

Hubungan Dukungan Suami dengan Penggunaan Kontrasepsi pada Wanita Nikah Usia Dini di Desa Banjarsari Kecamatan Sukatani Kabupaten Bekasi

Berdasarkan hasil penelitian pada tabel 4 terdapat $17(68 \%)$ wanita nikah usia dini yang kurang mendapatkan dukungan suami tidak menggunakan kontrasepsi. Bentuk dukungan suami dalam ber-KB berupa dukungan terhadap penggunaan kontrasepsi dan merencanakan jumlah keluarga. Dukungan suami dalam penggunaan kontrasepsi dapat berupa dukungan emosional seperti komunikasi interpersonal yang berhubungan dengan perencanaan jumlah anak yang diinginkan, dukungan penghargaan seperti mengantarkan istrinya untuk melakukan kunjungan ulang kontrasepsi, dukungan instrumental seperti suami menyediakan dana atau biaya yang dikeluarkan untuk memasang alat kontrasepsi, dan dukungan informasi seperti saran yang diberikan suami untuk menggunakan salah satu alat kontrasepsi (Rafidah et al 2009).

Hasil penelitian ini sesuai dengan hasil penelitian (Arliana et.al, 2013). Klien yang diberikan dukungan oleh suami akan menggunakan kontrasepsi secara konsisten sedangkan yang tidak mendapat dukungan suami akan sedikit menggunakan kontrasepsi. Hasil penelitian ini menunjukkan dukungan suami sangat mempengaruhi ibu untuk menggunakan kontrasepsi. Beberapa bentuk dukungan suami yang diberikan kepada ibu yang menggunakan kontrasepsi dalam penelitian ini yaitu memberikan saran dalam memilih kontrasepsi, memberikan biaya, mengantarkan ibu ketempat pelayanan kontrasepsi, dan mengingatkan ibu untuk melakukan kunjungan ulang. 
Hubungan Sumber Informasi dengan Penggunaan Kontrasepsi pada Wanita Nikah Usia Dini di Desa Banjarsari Kecamatan Sukatani Kabupaten Bekasi

Berdasarkan hasil penelitian pada tabel 5 terdapat 34 orang $(87.2 \%)$ yang mendapatkan informasi $\mathrm{KB}$ dari tenaga kesehatan memilih untuk menggunakan kontrasepsi. Sumber informasi biasanya diperoleh dari pengalaman bermacam-macam misalnya media massa, media elektronik, petugas kesehatan, keluarga atau teman dan lain-lain, sedangkan sumber informasi yang paling baik adalah tenaga kesehatan karena kemampuan dan pengetahuan yang dimiliki sesuai dengan keahliannya.

Hasil penelitan sesuai dengan hasil penelitian (Isma dkk.2013), bahwa perilaku seseorang dipengaruhi dari sumber informasi yang didapatkannya. Sumber informasi diperoleh melalui penyuluhan, konseling, pembinaan dan advokasi dalam penggunaan kontrasepsi. Tenaga kesehatan membantu klien memilih dan menentukan jenis kontrasepsi yang akan dipakai. Wanita nikah usia dini perlu mendapatkan informasi yang tepat dan benar, salah satunya informasi dari tenaga kesehatan sehingga dapat menggunakan kontrasepsi sesuai dengan kebutuhan dan keinginannya.

\section{KESIMPULAN}

Berdasarkan penelitian yang telah dilakukan pada 53 wanita nikah usia dini yang ada di Desa Banjarsari Kecamatan Sukatani Kabupaten Bekasi, maka dapat disimpulkan bahwa pengetahuan, tingkat pendidikan, dukungan suami, dan sumber informasi berhubungan dengan penggunaan kontrasepsi pada wanita nikah usia dini. Wanita nikah usia dini merupakan individu yang rentan mengalami masalah kesehatan reproduksi terutama saat hamil dan bersalin. Kehamilan dapat dicegah dengan penggunaan alat kontrasepsi. Jika kehamilan telah terjadi maka tenaga keseheatan dapat meminimalisir risiko komplikasi tersebut dengan pegawasan antenatal optimal serta persalinan yang bersih dan aman. Oleh karena itu wanita nikah usia dini disarankan diberi pengetahuan kontrasepsi yang bersumber dari tenaga kesehatan, didukung oleh suami dan memiliki pendidikan baik.

\section{DAFTAR PUSTAKA}

Arliana, W.O.D., Sarake, M., dan Seweng, A. 2013. Faktor yang berhubungan dengan Penggunaan Metode Kontrasepsi Hormonal pada Akseptor KB di Kelurahan Pasarwajo Kecamatan Pasarwajo Kabupaten Buton Sulawesi Tenggara. Universitas Hasanudin. Makasar.

Kementerian Kesehatan RI. 2012. Rencana Aksi Pelayanan Nasional Pelayanan Keluarga Berencan Tahun 2014-2015.Direktorat Jenderal Bina Gizi dan Kesehatan Ibu dan AnakKementerian Kesehatan RI. Jakarta

Kementerian Kesehatan RI. 2013. Riset Kesehatan Dasar 2013. Badan Penelitian dan Pengembangan Kesehatan Kementerian Kesehatan RI

Manuaba, Ida Ayu C.; Manuaba, Ida Bagus Gde Fajar; \& Manuaba, Ida Bagus Gde. 2009. Memahami Kesehatan Reproduksi Wanita. Jakarta : EGC

Notoatmodjo, Soekidjo. 2003. Pendidikan dan Perilaku Kesehatan. Jakarta : Rineka Cipta

Rafidah, Emilia Ova, dan Wahyuni, B. 2009. Faktor-faktor yang berhubungan dengan Pernikahan Usia Dini di Kabupaten Purworejo Jawa Tengah. Berita Kedokteran Masyarakat Volume 25 No. 2 Juni 2009.

Bappeda. 2014. Kependudukan dan Keluarga Berencana (KB). Dikases dari http://www.bappenas.go.id diakses tanggal 10 November 2016.

Chandra-Mouli V, Camacho AV, Michaud P. Who guidelines on preventing early pregnancy and poor reproductive outcomes among adolescents in developing countries. Journal of Adolescent Health vol 52 (2013) 517-522

Chandra-Mouli V, McCarraher DR, Phillips SJ ,Williamson NE, Hainsworth G. Contraception for adolescents in low and middle income countries: needs, barriers, and access. Reproductive Health 2014, $11: 1$

Chernick LS, Barriers to and Enablers of Contraceptive Use among Adolescent Females and their Interest in an Emergency Department-based 
Intervention. Contraception. 2015 March ; 91(3): 217-225

Eliason, Sebastian; Wiliams, John K.; Eliason, Cecilia; Novignon, Justice; \& Aikins, Moses. 2014. Determinants Of Modern Family Planning Use Among Women Of Reproductive Age In The Nkwanta District Of Ghana: A CaseControl Study. Journal Reproductive Health 2014, 11:65
Fadlyana, E,.dan Larasaty, S. 2009. Pernikahan Usia Dini dan Permasalahannya. Seri Pedriati volume II no. 2 Agustus 2009. Fakultas Kedokteran. Universitas Padjajaran

Rizkianti A, Amaliah N, Rachmalina R. Penggunaan Kontrasepsi pada Remaja Perempuan Kawin di Indonesia. Buletin Penelitian Kesehatan, Vol. 45, No. 4, Desember 2017: 257 - 26 